\title{
Graduates employability: An exploratory Literature Review
}

\author{
Aniss Moumen ${ }^{1 *}$, Nezha Mejjad ${ }^{2}$ \\ ${ }^{1}$ Laboratory of Engineering Sciences, National School of Applied Sciences, Ibn Tofail University, \\ Kenitra, Morocco \\ ${ }^{2}$ Laboratory of Applied Geology, Geomatics and Environment- Faculty of Sciences - Ben M'sik, \\ Hassan 2 University, Casablanca, Morocco
}

\begin{abstract}
This paper aims to present an exploratory literature review from the "Education and Training" journal indexed in Scopus, which has published 99 articles about "Graduate Employability" from 2005 to 2021. After cleaning, classifying and reading these articles with NVIVO; As a result, we have found that authors utilize: quantitative, qualitative, mixed and experimental methodology to address problems related to graduate attributes, graduate employability skills and constructs, enhance employability, self-employability perception and employers perceptions. Also, we have identified three famous conceptual frameworks to measure graduate employability: the Graduate Employability Development model [1], the CareerEDGE model [2] and the Career Management Employability model [3].
\end{abstract}

\section{Introduction}

Employability has an important impact on the social and economic context. The first definition for employability was the capability of an individual to integrate the job market [4]. Indeed, this integration makes the people more integrate into society and create more value for the economy.

Related to the previous works [4]-[7]. In the 1970s, employability became the attractivity of an individual for potential employers, appreciated by the result of functional tests, the ability to work and professional behaviours. With this definition, we distingue two meanings of employability. The first one is the labour market requirements, and the other hand, related to personal traits. In the $2000 \mathrm{~s}$, the definition of employability will integrate other attributes as mobility and knowledge of the labour market. However, this definition of employability did not make a difference between individuals after and before graduation.

In this paper, we are focusing on graduate and undergraduate employability. We want to explore the topics and the research methodology followed to study the population. We chose the "Education and Training" journal to elaborate this exploratory literature review.

*Corresponding author:aniss.oumoumen@uit.ac.ma 


\section{Graduate employability}

Graduate employability can be defined as the compilation of a series of soft and hard skills and abilities that a graduate can obtain to achieve and meet a desirable job requirement and succeed in his/her career [8]-[12]. Based on the related works that primarily started from the 1990s, we can separate this series of skills into two categories :

- Category 1: Guilbert et al., 2016 and Tholen, 2014 [13]-[14], propose that employability combines interior and exterior factors. The internal factors include personal knowledge and job skills, such as technical and team working skills, while the external factors include the labour market requirement.

- Category 2: Yorke and Knight, 2007, Tholen, 2014, Finch et al., 2013 [14]-[16], present a set of skills related to individual ability and a collection of competitive skills.

The table below gives an overview from literature review of the graduate employability dimensions :

Table 1. "Graduate Employability" factors [12]

\begin{tabular}{|c|c|c|}
\hline Year & Authors & Dimensions \\
\hline 2003 & $\begin{array}{l}\text { Weligamage and Siengthai, } 2003 \\
{[17]}\end{array}$ & $\begin{array}{l}\text { Communication Skills, General } \\
\text { Knowledge, Personality, Computer and } \\
\text { IT skills, Verbal Communication skills, } \\
\text { Realistic experience and Educational } \\
\text { Background }\end{array}$ \\
\hline 2005 & $\begin{array}{c}\text { McQuaid and Lindsay, } 2005 \\
\text { [6] }\end{array}$ & $\begin{array}{l}\text { Personal and Social Attributes, } \\
\text { Leadership Skills, Communication Skills } \\
\text { and Teamwork Skills }\end{array}$ \\
\hline 2014 & $\begin{array}{l}\text { Paadi, } 2014 \\
{[18]}\end{array}$ & $\begin{array}{l}\text { Teamwork, Communication, Analytic \& } \\
\text { Critical Thinking and IT skill }\end{array}$ \\
\hline 2016 & $\begin{array}{c}\text { Liyanage et al., } 2016 \\
{[19]}\end{array}$ & $\begin{array}{l}\text { Graduates' realistic knowledge, Logical } \\
\text { ability, Dedication to work, } \\
\text { communication \& IT skills, Management } \\
\text { Skills and Positive Attitudes }\end{array}$ \\
\hline 2016 & $\begin{array}{c}\text { Ambepitiya, } 2016 \\
{[20]}\end{array}$ & $\begin{array}{l}\text { Academic Knowledge, Soft, Practical and } \\
\text { Technical Skill }\end{array}$ \\
\hline 2020 & $\begin{array}{c}\text { Jayasingha and Suraweera, } 2020 \\
{[21]}\end{array}$ & $\begin{array}{l}\text { Academic Performance, Technical Skills } \\
\text { Communication Skills, Personality, } \\
\text { Leadership \& Motivational Skills; } \\
\text { and Teamwork \& Problem-Solving Skills }\end{array}$ \\
\hline
\end{tabular}




\section{Methodology}

To realize this exploratory literature review focusing on "Graduate employability", we use "Scopus" as a scientific database and formulate the requests bellow (Table 2) :

Table 2. Search Request about "Graduate Employability" on "Scopus".

\begin{tabular}{|c|c|c|c|c|}
\hline & $\begin{array}{c}\text { Request } \\
\text { (Keywords and } \\
\text { operator) }\end{array}$ & Top 3 sources titles & $\begin{array}{l}\text { References } \\
\text { by journal }\end{array}$ & $\begin{array}{c}\text { Total } \\
\text { References }\end{array}$ \\
\hline \multirow{3}{*}{1} & \multirow{3}{*}{ "Employability" } & Education And Training & 125 & \multirow{3}{*}{9465} \\
\hline & & $\begin{array}{l}\text { Higher Education Skills } \\
\text { And Work Based Learning }\end{array}$ & 108 & \\
\hline & & $\begin{array}{l}\text { Studies In Higher } \\
\text { Education }\end{array}$ & 78 & \\
\hline \multirow{3}{*}{2} & \multirow{3}{*}{$\begin{array}{c}\text { "Employability" } \\
\text { and } \\
\text { "Student" }\end{array}$} & Education And Training & 99 & \multirow{3}{*}{3616} \\
\hline & & $\begin{array}{l}\text { Higher Education Skills } \\
\text { And Work Based Learning }\end{array}$ & 94 & \\
\hline & & $\begin{array}{l}\text { Studies In Higher } \\
\text { Education }\end{array}$ & 52 & \\
\hline \multirow{3}{*}{3} & \multirow{3}{*}{$\begin{array}{l}\text { "Graduate } \\
\text { Employability" }\end{array}$} & Education And Training & 32 & \multirow{3}{*}{728} \\
\hline & & $\begin{array}{l}\text { Higher Education Skills } \\
\text { And Work Based Learning }\end{array}$ & 24 & \\
\hline & & $\begin{array}{l}\text { Industry And Higher } \\
\text { Education }\end{array}$ & 23 & \\
\hline
\end{tabular}

As a result, we found more than 9000, 3000 and 700 references from requests 1, 2 and 3, which testifies the subject's importance. From these results, we found the classification by journals as presented in the table above.

To elaborate this literature review, we have chosen to work from request two and focusing on the publications of the "Education and Training" journal that regroup 99 articles. Indeed, "Education and Training" (ISSN:0040-0912) is a peer-reviewed journal, created and indexed on Scopus from 1959 (62 years) and also by Web of Science (in Social Sciences Citation Index), published by Emerald. This journal has published 556 Issues (more than 3000 articles), from volume 1 to 63 (on 2021), and his has H-index is 65. His topics: Social sciences, Education, Management.

From the corpus created from this journal, as previous works about literature review on employability [22], [23], we have processed this literature review by NVIVO. Figure (Fig.1) below summarize the steps of this exploratory review :

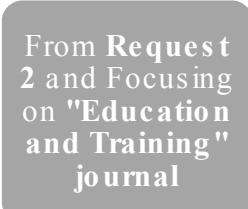

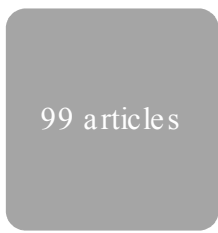
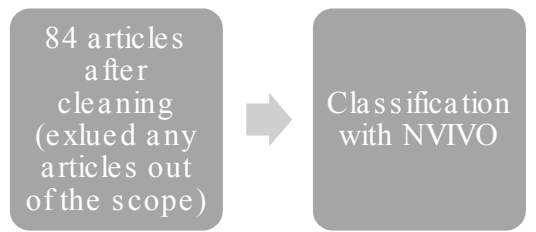

Fig. 1. Processing steps to elaborate an exploratory literature review on "Graduate Employability." 


\section{Results and discussion}

\subsection{Meta-analysis :}

From the corpus of "Education and Training" articles concerning "Graduate Employability", we found that the publication in this topic starts from 2005, the first peak was achieved in 2010. Also, we observe that after 2014 the number of publications increases considerably. In 2020 the number of publications was doubled. The figure and table below give more information about the publications.

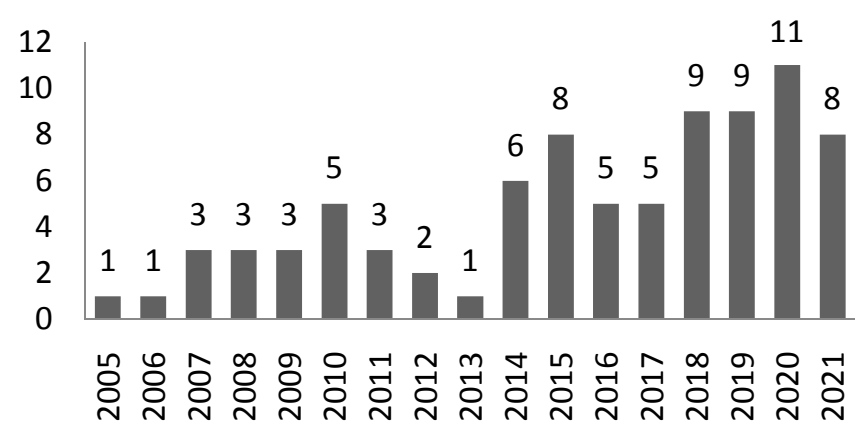

Fig. 2. Publication years in the corpus

Table 3. Publication description.

\begin{tabular}{|c|c|c|c|c|c|c|}
\hline Journal & Period & Total & Mean & Min & Max & Median \\
\hline Education and Training & $2005-2021$ & 83 & 4,88 & $1(2005)$ & $11(2020)$ & $5(2010)$ \\
\hline
\end{tabular}

Concerning the citation count, we observe that this journal has high citations, that why it is in the first Quartile (Q1) according to the Scopus classification. The most cited article is from Pool L.D and Sewell, P (ref), about "CareerEDGE Model", one of the measurement models of Graduate Employability.

Table 4. Top 5 of most cited articles.

\begin{tabular}{|c|c|c|c|c|}
\hline Title & Authors & Year & $\begin{array}{c}\text { Volume, } \\
\text { Issue, pages }\end{array}$ & Citation \\
\hline $\begin{array}{c}\text { The key to employability: } \\
\text { Developing a practical model of graduate } \\
\text { employability [2] }\end{array}$ & $\begin{array}{c}\text { Pool, } \\
\text { L.D., Sewell, P. }\end{array}$ & 2007 & $\begin{array}{c}49(4), \text { pp. 277- } \\
289\end{array}$ & \\
\hline $\begin{array}{c}\text { Connecting enterprise and graduate } \\
\text { employability: }\end{array}$ & & & $\begin{array}{c}49(8-9), \text { pp. } \\
605-619\end{array}$ & 424 \\
$\begin{array}{c}\text { Challenges to the higher education culture } \\
\text { and curriculum? [24] }\end{array}$ & Rae, D. & 2007 & & 189 \\
\hline $\begin{array}{c}\text { Effects of business internships on job } \\
\text { marketability: The employers' perspective } \\
{[25]}\end{array}$ & $\begin{array}{c}\text { Gault, J., Leach, } \\
\text { E., Duey, M. }\end{array}$ & 2010 & $\begin{array}{c}52(1), \text { pp. 76- } \\
88\end{array}$ & 131 \\
\hline $\begin{array}{c}\text { Developing employability skills: Peer } \\
\text { assessment in higher education }\end{array}$ & Cassidy S. & 2006 & $\begin{array}{c}48(7), \text { pp. 508- } \\
517\end{array}$ & 128 \\
\hline $\begin{array}{c}\text { Forms of graduate capital and their } \\
\text { relationship to graduate employability } \\
{[26]}\end{array}$ & Tomlinson, M. & 2017 & $\begin{array}{c}59(4), \text { pp. 338- } \\
352\end{array}$ & 107 \\
\hline
\end{tabular}




\subsection{Topics analysis :}

The authors of the papers analyzed in this study use keywords to define and classify their works. From these keywords, we can make a cloud word that dresses the occurrence and co-occurrence of the words in the corpus. The figure below represents the cloud word of the authors' keywords :

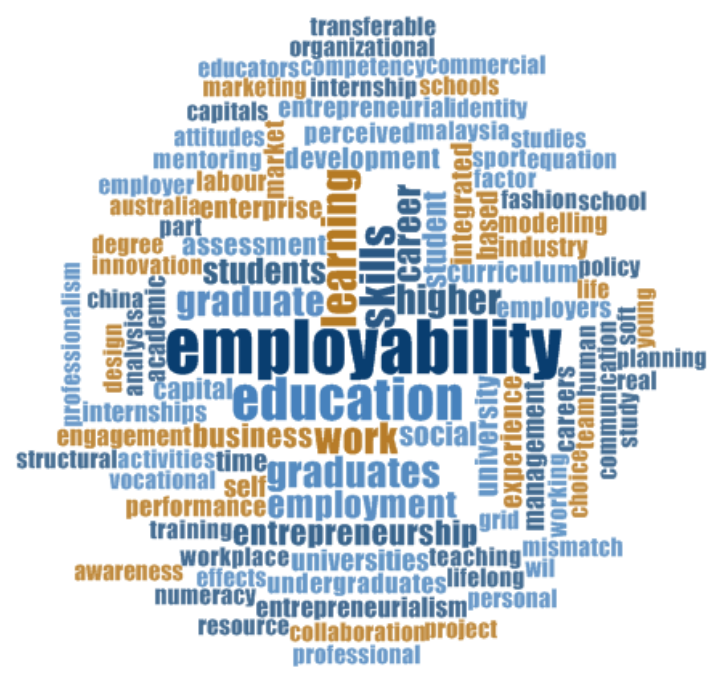

Fig. 3. Publication years in the corpus

As we can conclude from the figure above, the most important topics faced by the authors are :

- Employability skills

- Graduate attributes and skills

- Vocational graduates

- Employers perception

- Self-Perceived Employability (SPL)

- Mismatch between graduates skills and Labor markets requirements

- Internship

- Time management

- Teamwork

- Soft skills/Technical skills

- Numeracy

- Entrepreneurialism/Entrepreneurialship

- Students/employers attitudes

- Communication

- Project learning

- Engagement learning

- Work-Integrated Learning (WIL)

- Attitudes and personal traits of graduates 


\subsection{Methodologies analysis :}

This review found that the authors follow multiple research methodologies and approaches from both descriptive and experimental catalogues. The quantitative approach is used in 39 references, and in 24 references, the authors use the qualitative approach. Also, the authors of 10 references use mixed methods. However, just four references from the "Education and Training" use experimental/quasi-experimental methods. The table below summarizes this situation, with some indication about sampling and data analysis technics.

Table 5. Research Methodologies, approaches, sampling and data analysis techniques.

\begin{tabular}{|c|c|c|c|c|c|c|c|}
\hline \multirow{2}{*}{$\begin{array}{c}\text { Methodolog } \\
\text { y }\end{array}$} & \multirow{2}{*}{ Approaches } & \multirow{2}{*}{ Instrument } & \multirow{2}{*}{ Population } & \multicolumn{2}{|c|}{ Sample size } & \multirow{2}{*}{$\begin{array}{c}\text { Data } \\
\text { analysis } \\
\text { technics }\end{array}$} & \multirow{2}{*}{ Ref } \\
\hline & & & & Min & Max & & \\
\hline \multirow{3}{*}{ Descriptive } & Quantitative & Questionnaire & \multirow{3}{*}{$\begin{array}{c}\text { Undergraduates, } \\
\text { graduates, } \\
\text { employers, } \\
\text { managers, } \\
\text { academics }\end{array}$} & 37 & 1502 & $\begin{array}{c}\text { Regression, } \\
\text { Classificatio } \\
\text { n, SEM, } \\
\text { PLS, } \\
\text { Hypothesis } \\
\text { Tests, } \\
\text { Multivariate } \\
\text { analysis }\end{array}$ & 39 \\
\hline & Qualitative & $\begin{array}{l}\text { Interviews, } \\
\text { Focus group }\end{array}$ & & 6 & 86 & $\begin{array}{l}\text { Thematic } \\
\text { analysis }\end{array}$ & 24 \\
\hline & Mixed & $\begin{array}{c}\text { Questionnaire, } \\
\text { Interviews, } \\
\text { Focus groups, } \\
\text { E-mail } \\
\text { discussions, } \\
\text { Writing } \\
\text { comments }\end{array}$ & & 12 & 122 & $\begin{array}{c}\text { Exploratory } \\
\text { Factor } \\
\text { Analysis, } \\
\text { critical } \\
\text { incident } \\
\text { technique }\end{array}$ & 10 \\
\hline \multicolumn{2}{|c|}{$\begin{array}{c}\text { Experimantal/Quasi- } \\
\text { experimental }\end{array}$} & $\begin{array}{c}\text { Instructional } \\
\text { activities, } \\
\text { prototype } \\
\text { interventions, } \\
\text { work-based } \\
\text { learning } \\
\text { modules, } \\
\text { experiential } \\
\text { learning } \\
\text { framework } \\
\end{array}$ & $\begin{array}{l}\text { Students, } \\
\text { Experts }\end{array}$ & 30 & 120 & $\begin{array}{l}\text { Case study } \\
\text { analysis }\end{array}$ & 4 \\
\hline \multicolumn{7}{|c|}{ Conceptual } & 6 \\
\hline \multicolumn{7}{|c|}{ Total } & 83 \\
\hline
\end{tabular}

We can conclude from this table above: 1) the sampling of all the quantitative works starts from 30 individuals to more than 1000. 2) The authors use hypothesis tests (parametric and no parametric), regression or multivariance analysis as occurrent data analysis technics. 3) Students and Experts are the individuals concerned by all the empirical studies. 


\section{Conclusion}

This paper present an exploratory literature review from the "Education and Training" journal. We have pointed that authors utilize: descriptive and experimental methodology to address problems related to graduate employability, sometimes from the employers' views or students side.

Also, from conceptual studies, we have deducted three famous conceptual frameworks to measure graduate employability: the Graduate Employability Development model [1], the CareerEDGE model [27] and the Career Management Employability model [3].

However, we faced difficulties with identifying the population characteristics and sample size concerning experimental/quasi-experimental studies during this exploratory literature review. As a perspective, we will include more references to conduct a systematic literature review and prepare our empirical study with mixed methods with Moroccan Engineering Students.

\section{References}

1. L. Harvey, «Employability and diversity », Retrieved from www2. wlv. ac. uk/webteam/confs/socdiv/sdd-harvey-0602. doc, 2002.

2. L. D. Pool et P. Sewell, « The key to employability: developing a practical model of graduate employability », Education+ Training, 2007.

3. R. Bridgstock, « The graduate attributes we've overlooked: Enhancing graduate employability through career management skills », Higher Education Research \& Development, vol. 28, $\mathrm{n}^{\mathrm{o}}$ 1, p. 31-44, 2009.

4. B. Gazier, «L'employabilité: brève radiographie d'un concept en mutation », Sociologie du travail, p. 575-584, 1990.

5. N. Deacken, « Le sentiment d'employabilité des cadres seniors, secteur privé français: définition, opérationnalisation et déterminants. ", PhD Thesis, Aix-Marseille, 2015.

6. R. W. McQuaid et C. Lindsay, "The concept of employability », Urban studies, vol. 42, no 2, p. 197-219, 2005.

7. S. Zgoulli-Swalhi, «Employabilité et implication organisationnelle: quelles pratiques RH? », PhD Thesis, Université Montpellier II-Sciences et Techniques du Languedoc, 2014.

8. Y. Chen, " Graduate employability: the perspective of social network learning ", Eurasia Journal of Mathematics, Science and Technology Education, vol. 13, nº 6, p. 2567-2580, 2017.

9. M. Tomlinson, " Graduate employability: A review of conceptual and empirical themes », Higher Education Policy, vol. 25, n 4, p. 407-431, 2012.

10. J. Reid, « Redefining "Employability" as something to be achieved: Utilising Tronto's conceptual framework of care to refocus the debate », Higher Education, Skills and Work-Based Learning, 2016.

11. S. Kalfa et L. Taksa, "Cultural capital in business higher education: reconsidering the graduate attributes movement and the focus on employability », null, vol. 40, $\mathrm{n}^{\circ} 4$, p. 580-595, avr. 2015, doi: 10.1080/03075079.2013.842210.

12. M. S. Hosain, M. A. A. Mustafi, et T. Parvin, « Factors affecting the employability of private university graduates: an exploratory study on Bangladeshi employers », PSU Research Review, vol. ahead-of-print, $\mathrm{n}^{\mathrm{o}}$ ahead-of-print, janv. 2021, doi: 10.1108/PRR01-2021-0005. 
13. L. Guilbert, J.-L. Bernaud, B. Gouvernet, et J. Rossier, « Employability: review and research prospects », International Journal for Educational and Vocational Guidance, vol. $16, n^{\circ} 1$, p. 69-89, 2016.

14. G. Tholen, « Graduate employability and educational context: a comparison between Great Britain and the Netherlands », British Educational Research Journal, vol. 40, $\mathrm{n}^{\circ}$ 1, p. 1-17, 2014.

15. M. Yorke et P. Knight, « Evidence-informed pedagogy and the enhancement of student employability », Teaching in higher education, vol. 12, $\mathrm{n}^{\circ}$ 2, p. 157-170, 2007.

16. D. J. Finch, L. K. Hamilton, R. Baldwin, et M. Zehner, « An exploratory study of factors affecting undergraduate employability », Education + Training, vol. 55, $\mathrm{n}^{\circ} 7$, p. 681-704, janv. 2013, doi: 10.1108/ET-07-2012-0077.

17. S. Weligamage et S. Siengthai, «Employer needs and graduate skills: the gap between employer expectations and job expectations of Sri Lankan university graduates », 2003.

18. K. Paadi, «Perceptions on employability skills necessary to enhance human resource management graduates prospects of securing a relevant place in the labour market », European Scientific Journal, 2014.

19. Ptd. Liyanage, Ua. Kumara, et Mpk. Withanawasam, «Employability of the Management Graduates in Sri Lanka: A Case Study », 2016.

20. K. R. Ambepitiya, " Employability of graduates of public and private management education institutes: A case study of two institutes in Sri Lanka », 2016.

21. D. Jayasingha et S. Suraweera, "An analysis of the factors affecting the graduates" employability in case of Rajarata university of Sri Lanka », IRE Journals, vol. 3, n ${ }^{\circ} 12$, p. 10-24, 2020.

22. A. Moumen, «A Systematic Literature Review of Youth Employment and Employability in Morocco: Role of Data Mining Techniques ».

23. A. MOUMEN, E. H. BOUCHAMA, et Y. E. B. EL IDIRISSI, « Data mining techniques for employability: Systematic literature review », in 2020 IEEE 2nd International Conference on Electronics, Control, Optimization and Computer Science (ICECOCS), 2020, p. 1-5.

24. D. Rae, « Connecting enterprise and graduate employability: Challenges to the higher education culture and curriculum? », Education and Training, vol. 49, n 8-9, p. 605-619, 2007, doi: 10.1108/00400910710834049.

25. J. Gault, E. Leach, et M. Duey, « Effects of business internships on job marketability: The employers' perspective », Education and Training, vol. 52, n 1, p. 76-88, 2010, doi: 10.1108/00400911011017690.

26. S. Cassidy, " Developing employability skills: Peer assessment in higher education », Education and Training, vol. 48, $\mathrm{n}^{\mathrm{o}}$ 7, p. 508-517, 2006, doi: 10.1108/00400910610705890.

27. L. Dacre Pool, P. Qualter, et P. J. Sewell, « Exploring the factor structure of the CareerEDGE employability development profile », Education + Training, vol. 56, $\mathrm{n}^{\circ}$ 4, p. 303-313, janv. 2014, doi: 10.1108/ET-01-2013-0009. 